\title{
Durkheim on 'Primitive' Religion: A Reappraisal
}

\author{
Zacharias Kotzé ${ }^{1}$ \\ Department of Biblical and Ancient Studies, University of South Africa
}

\begin{abstract}
Durkheim on 'Primitive' Religion: A Reappraisal. Durkheim is widely regarded as one of the most prominent scholars of the sociology of religion. While many scholars of the late nineteenth and early twentieth centuries have been criticised for racist bias in support of imperial projects by decolonial and postcolonial thinkers in recent years, Durkheim is often celebrated for his rejection of the questionable evolutionist ideas of his time. This paper reconsiders Durkheim's theory of so-called 'primitive' religion in relation to other preeminent theories of religion of his era, such as Edward Burnett Tylor's theory of religion as animism. Utilising a postcolonial approach, the paper firstly critically examines the use of concepts such as 'primitive' in Tylor and Durkheim's anthropological and sociological theories of religion, respectively. It is demonstrated that, although Durkheim was overtly critical of evolutionist approaches of his day and attempted to break from this dominant paradigm by focusing more on social structures, rather than temporal development, he failed in freeing himself from prevalent racist assumptions. Despite this failing and the fact that his theorising of religion as totemism has long since fallen out of favour, however, his focus on the social nature and function of religion should still be celebrated.

Sociológia 2021, Vol. 53 (No. 3: 225-237)

https://doi.org/10.31577/sociologia.2021.53.3.8
\end{abstract}

Key words: Durkheim; postcolonial theory; primitive; totemism

\section{Introduction}

The study of religion and its origins was of central importance to many thinkers and philosophers of the nineteenth and twentieth centuries. Émile Durkheim $(1858$ - 1917) was no exception. Although primarily regarded as a sociologist, and indeed a founding father of sociology as an academic discipline and a principal architect of modern social science, Durkheim devoted much of his time and effort to explain religion (cf. Durkheim 1995[1912]). Although the bulk of his work is usually interpreted as the presentation of social facts in a neutral manner, Durkheim did at times attempt to demonstrate how European societies could maintain their integrity and unity in an era where traditional social and religious values were in decline and increasingly overshadowed by new institutions and secularism (cf. Durkheim 1995[1912]: 418-440). However, although Durkheim and his associates started out studying modern Europe, they ended by studying it hardly at all (Vogt 1976: 33). Durkheim had a strong interest in ethnography and would eventually found a school of social scientists whose near exclusive focus was non-western peoples.

A recurring theme in Durkheim's work was 'primitive' thought and 'primitive' social phenomena. For example, his renowned The elementary

\footnotetext{
1 Address: Zacharias Kotzé, DPhil., Department of Biblical and Ancient Studies, University of South Africa. P. O. Box 392, Unisa 0003, South Africa. E-mail: zkotzech@yahoo.com
} 
forms of religious life, first published in 1912, had as its goal the study of the most 'primitive' religious system known to him at the time: "I propose in this book to study the simplest and most primitive religion that is known at present, to discover its principles and attempt an explanation of it" (Durkheim 1995[1912]: 1). Throughout his academic endeavours he referred to a hypothetical 'then' to be contrasted with the concrete 'now.' In the decade prior to WWI, being a Durkheimian already essentially meant being a student of 'primitive' peoples and societies. Durkheimian sociology of the 1920's and 1930's constituted what one usually thinks of as 'cultural anthropology.'

According to Durkheim, the best method for researching the social and intellectual nature of religion was to investigate 'primitive' religion in which, according to him, the facts were simpler and the relations between them were more apparent:

"Therefore, my study of a very archaic religion will not be for the sheer pleasure of recounting the bizarre and the eccentric. I have made a very archaic religion the subject of my research because it seems better suited than any other to help us comprehend the religious nature of man, that is, to reveal a fundamental and permanent aspect of humanity" (Durkheim 1995[1912]: 1).

Vogt (1976) identifies several factors that may have contributed to the Durkheimians' near exclusive focus on 'primitive' peoples. A prominent 'internal' factor was related to Durkheim's preoccupation with religion and his belief that the religious nature of man constituted an essential aspect of humanity. With his Elementary forms Durkheim not only wanted to demonstrate the cohesive function of religion in society, but also point out that religion contributed significantly to human knowledge:

"It has long been known that the first systems of representations that man made of the world and himself were of religious origin. ... Further, and less often noted, religion has not merely enriched a human intellect already formed but in fact has helped to form it. Men owe to religion not only the content of their knowledge, in significant part, but also the form in which that knowledge is elaborated" (Durkheim 1995[1912]: 8).

Unfortunately, Vogt (1976) glosses over political and ideological motivations for this endeavour that may have contributed to a more nuanced understanding of Durkheim's discourse on the 'primitive.' In his study on Durkheim's theory of primitive kinship, Kuper (1985: 224) argues that Durkheim's preoccupation with the study of 'primitive' society was related to his goal of establishing a rational, scientific morality that would not be dependent on either religion or the values of the family. 
Durkheim is often celebrated for his rejection of the racist stereotypes in the thinking of his contemporaries. For example, his critique of Tylor's understanding of religion as animism is often understood as a critique of perceptions that 'primitive' societies were inferior and radically different from European civilisation. However, although Durkheim argued that modern society is fundamentally the same as 'elementary' societies, his concept of social evolution, which can be found throughout his works, is still problematic. Commenting on Durkheim's formulations about 'primitive' ways of thinking, Merllié (2012) draws attention to the fact that Durkheim's notion of the 'primitive' often implied the evolutionary sense of 'earliest' rather than the more neutral notion of 'elementary.' Although Durkheim insisted on the similarities between 'primitive' and 'civilised' cultures, he still assumed that all societies followed the same path of progression. Further, as will be demonstrated below, his views of the evolutionary change of societies equate growth with progress. Postcolonial theorists have argued that the simple distinction between 'primitive' and 'civilised' was used by scholars of the nineteenth and early twentieth centuries to represent the hierarchies on which imperialism was based and to actively perpetuate such hierarchies. Although Durkheim may have criticised the racial stereotypes of his contemporaries and viewed 'elementary' societies as essentially similar to 'civilised' European societies, his views are still problematic, although in different ways. Merllié concludes his study by correctly observing that Durkheim's discourse on the 'primitive' has not been sufficiently problematised. This paper will re-evaluate Durkheim's critique of Tylor's explanation of animism as the most 'primitive' form of religion before considering the ways in which his own conceptualisation of 'primitive' religion as totemism can be regarded as problematic from a postcolonial perspective.

\section{A postcolonial perspective}

Although it is generally agreed that the world has been affected to some degree by nineteenth-century European imperialism, the continuing effects of colonial and neo-colonial power have remained largely unnoticed (Ashcroft et al. 2013: 1). Postcolonial analysis increasingly exposes the nature and impact of inherited power relations and their prevailing influence on culture and politics. In this approach, issues such as race, class, economics, and gender are considered in the context of their relationship with the colonialist past, since the structures of power established by the colonising process have remained pervasive, although often hidden, throughout the world. The postcolonial endeavour draws upon a wide variety of theoretical frameworks and methodologies to challenge power relations in an atmosphere of intellectual exchange. The overarching concern is the identification of colonialist 
constructions of knowledge as they were used to justify and maintain the subordination of colonised groups (Goulet 2011: 631). In its application to the study of religion, it challenges colonialist assumptions about religion as rooted in Christian and secular morality while drawing attention to the impact of imperial formulations about religion with reference to lower classes and the marginalised.

The intellectual history of postcolonialism has been marked by the utilisation of especially Marxist theory and postmodernism in order to come to new understandings of history and knowledge (Gandhi 1998: viii). The nature and scope of this endeavour is possibly best understood with reference to a few seminal texts that have contributed most significantly to the formulation of postcolonial theory. In his Orientalism (1979), Edward Said suggests that the West has consistently depicted the Islamic Middle East as backward and uncivilised. Said argues that the non-west is construed as irrational, exotic, spiritual, and effeminate in contrast to the west, which is presented as rational, modern, secular, and masculine. Far from constituting objective knowledge, these Manichean stereotypes served the function of asserting western power over and dominance of the east.

Although Said's Orientalism is possibly the most cited and accessible text on postcolonial theory, the work of the Martiniquan psychiatrist, Franz Fanon, is arguably of equal importance in that it discusses responses to colonialist power and the ways in which anti-colonial sentiment might address the task of decolonisation (cf. Ashcroft et al. 2013: 99). In his Black skin, white masks (1968[1952]) Fanon shares the insights of his clinical study of the effects of racism and colonial domination on the psychology of the colonised and his Marxist analysis of social and economic control. From this he develops the idea of a comprador class, or élite, who exchanged roles with the white colonial dominating class without any real attempt to decolonise their societies. Hence, the black skin of these élites is masked by their adoption of the values of the white colonial powers. While acknowledging the need for indigenous intellectuals to rediscover pre-colonial knowledge and identities in his The wretched of the earth (Fanon 1967[1961]), he warns that such pasts could easily be mythologised and used to create new élite power groups masquerading as liberators.

Since the publication of these, and other, seminal works, postcolonial studies have developed conceptual vocabularies that have become increasingly refined and have proven particularly useful for any analysis of the effects of colonialism on the creation and dissemination of knowledge. For example, the triple-mediation process of knowledge formation as described by Chidester (2014) in his work on empire and religion seems to be of particular interest and value. Chidester demonstrates that knowledge about religion and religions had 
been created in a complex process involving indigenous, colonial, and imperial forces. In the indigenous context, indigenous informants had to negotiate between ancestral traditions and Christian missions. On the colonial front, local experts, usually Christian missionaries and travellers, generated reports about indigenous religious systems specifically to address the demands of scholars working in the metropolitan centres of Europe. In the imperial mediation, the metropolitan theorists mediated between hypothetical reconstructions of the 'primitive' past and contested civilising projects in the creation of imperial theories. While Chidester has shown, as will be demonstrated below, that Tylor's theory of animism as the origin of religion was developed making use of this triple mediation process, Durkheim has also been criticised for a complete lack of critical stance towards the ethnographic data supplied to him by travellers, police agents, and priests in his project to depict Arunta religion as the most 'primitive' and elementary (Thomassen 2016: 180). However, Durkheim also severely criticised Tylor's theory of religion as animism for its racist assumptions. Unfortunately, however, he never succeeded in freeing himself from the problematic evolutionist ideas of his age and therefore, unwittingly, contributed to the imperial and colonial discourses of his time.

\section{Durkheim on 'primitive' religion}

In his account of the invention and reinvention of the myth of 'primitive' society, Kuper (2005: 3) notes that 'primitive' society was first studied by lawyers in the nineteenth century before it became one of the projects that made anthropology into a science. The study of 'primitive' society was a specialised pursuit within a much broader discourse that embraced the studies of 'primitive' mentality and speculations about the origin of language and religion. All these topics were connected to the Darwinian question of human origins. Most sociological and anthropological treatises on 'primitive' society were authored in the second half of the nineteenth century and the beginning of the twentieth century. Ashcroft et al. (2013: 198) suggest that the need to draw a binary distinction between 'civilised' and 'primitive' was inextricably linked to the need of imperial powers to establish dominance over subject peoples and thereby justify the imperial enterprise.

Durkheim's interest in so-called 'primitive' peoples and elementary forms is evidenced throughout his own writings (cf. Wityak - Wallace 1981: 61). Much more than a passing interest, the study of the 'primitive' represented a focal topic of research for the development of French sociology and anthropology. Unsurprisingly, one finds an abundance of ethnographic data in most of Durkheim's works (cf. Durkheim 1984[1893]: 74-102; 1995[1912]: 158-166). In his initial work, focusing on the societal division of labour and suicide (Durkheim 1984[1893], 1951[1897]), respectively, Durkheim's reference to 
'primitive' societies functioned as a point of contrast that potentially elucidated social events in modern society. In the process, he makes ample use of racial stereotypes that were typical of European thinking at the time. In his Division of Labour in Society (1984[1893]: 88-89), for example, he affirms that "the more primitive societies are, the more resemblances there are between the individuals from which they have been formed. ... By contrast, among civilised peoples two individuals can be distinguished from one another at a first glance, and without any prior initiation." He draws pseudo-scientific support for this dubious taxonomy of racial characteristics by referring to Hippocrates' stereotyping of the Scythians and Waitz' racist comments on indigenous Americans. Much more sinister, however, is his reference to what he calls objective proof for this homogeneity in 'primitive' peoples provided by the study of Gustave Le Bon (Durkheim 1984[1893]: 89):

\begin{abstract}
"Dr Lebon was able to establish objectively this homogeneity, which increases as one goes further back in time towards the origins. He compared skulls belonging to different races and societies and found that the differences in cranial capacity existing between individuals of the same race are much greater according to how advanced the race is on the ladder of civilization. ... [T] he differences in volume between the largest adult male craniums and the smallest amounts in round figures to 200 cubic centimetres for the gorilla, 280 for the untouchables of India, 310 for the Australian aborigine, 350 for the ancient Egyptian, 470 for the twelfth-century Parisian, 600 for the modern Parisian, 700 for the German."
\end{abstract}

The conclusions of such unconvincing racial taxonomies, though continually contradicted by actual observation, have remained stubbornly persistent to the present day (Ashcroft et al. 2013: 200-201). In the nineteenth century they were used to affirm that variations in the constitution and behaviour of individuals were to be explained as the expression of different biological types, that the difference in racial types accounted for differences between culture, that racial taxonomies explained the superiority of Europeans and Aryans in particular, and that conflict between nations emerged from innate characteristics. From a postcolonial perspective it is important to note that this need to establish a distinction between the 'primitive' and the 'civilised' served an important political function in the context of nineteenth century European imperialism:

"Race is particularly pertinent to the rise of colonialism, because the division of human society in this way is inextricable from the need of colonialist powers to establish a dominance over subject peoples and hence justify the imperial enterprise. Race thinking and colonialism are imbued with the same impetus to draw a binary distinction between "civilized" and "primitive" and the same necessity for the hierarchization of human types. By translating the fact of colonial oppression into a 
justifying theory, however spurious, European race thinking initiated a hierarchy of human variation that has been difficult to dislodge. Although race is not specifically an invention of imperialism, it quickly became one of imperialism's most supportive ideas, because the idea of superiority that generated the emergence of race as a concept adapted easily to both impulses of the imperial mission: dominance and enlightenment" (Ashcroft et al. 2013: 198-199).

Chidester (2014) was able to demonstrate how Tylor's anthropological theory of animism, as developed in his Primitive culture (1871) depended on colonial mediations of Eurocentric ideas. Importantly, Chidester argues that Tylor's theory of religion, defined as 'the belief in spiritual beings,' was developed in the context of evolutionary theories about the relationship between human and animal psychology. Tylor participated in conferences where he presented together with phrenologists who, based on the form and measurements of skulls, argued that so-called 'savages' were morally and intellectually inferior to Westerners. In line with the evolutionary theory of his time, Tylor suggested that animals and 'primitive' humans shared the tendency to ascribe life to inanimate objects, which lies at the basis of all religions. He further suggested that this 'primitive' mentality was to be erased in the interest of progress. Chidester (2014) expertly demonstrated that Tylor's theory of animism was based on the misrepresentation and decontextualization of reports about Zulu dreaming from colonial middlemen in South Africa. In particular, Tylor made use of The religious system of the Amazulu $(1868$ - 1870) by the Anglican missionary, Henry Callaway. Omitting crucial detail about colonial disruptions and conflict leading to psychological trauma, Tylor based his theory on the dreams of a diviner who, according to him, could not distinguish between dreams and visions in a waking state.

A century earlier, Durkheim, too, severely criticised the plausibility of Tylor's theory of religion as the belief in spiritual beings in his Elementary forms. Durkheim began by offering a broader definition of religion, namely a unified system of beliefs and practices relative to the sacred, which serves to unite a community of believers. In the following chapter, he carefully evaluates Tylor's animistic approach to religion. In Durkheim's analysis, Tylor's explanation involved three steps. Firstly, 'primitive' humans came up with the notion of a soul that inhabited the body and explained dreams. When a person dreamed of visiting a foreign place, 'primitive' humans believed that their soul left the body during sleep. In the next step, the idea of spirits emerged. In the animist explanation, souls, which animated the body while alive, turned into spirits after death. Early humans believed that these spirits had an independent existence and needed to be placated with sacrifices and other ritual practices. In the third development, early humans started to believe that inanimate objects, 
such as the sun, moon, mountains, animals, and plants, could be inhabited by spirits.

Durkheim was not convinced by Tylor's animist explanations. For example, he questioned the theory that early humans understood the soul as a double, which could leave the body at night. Rather, in his view, the early humans probably understood dreams as a kind of memory. Further, Durkheim did not believe that 'primitive' peoples afforded as much attention to their dreams as assumed by Tylor. In addition, in Durkheim's view, the belief in spirits preceded the explanation of dreams as a soul leaving the body during sleep, which was clearly distinguished from ordinary dreaming in so-called 'primitive' cultures. From the outset, Durkheim (2012[1912]: 3) distances himself from theories that denigrated 'primitive' religion and assumptions that Christianity was superior:

"All are religions equally, just as all living beings are equally alive, from the most humble plastids up to man. So when we turn to primitive religions it is not with the idea of depreciating religion in general, for these religions are no less respectable than the others. They respond to the same needs, they play the same role, they depend upon the same causes."

Not surprisingly, Durkheim is often celebrated for his rejection of the racist ideas of his time. The question remains, however, to what extend Durkheim succeeded in freeing his own theory of 'primitive' religion from questionable evolutionary formulations. As demonstrated with reference to Tylor's animistic explanation of religion, it was common for anthropologists and sociologists of the nineteenth century to believe that Western culture was the contemporary pinnacle of social evolution. This classical theory of social evolution is also sometimes called unilineal evolution, since different societies are thought to occupy a status on a single imaginary line that moves from most 'primitive' to most 'civilised.' During the Middle Ages most Europeans believed that societies on Earth were in a state of decline. During the Age of Enlightenment, however, European self-confidence grew, and prominent thinkers started to speculate that societies progressed through stages of increasing development. For example, both Auguste Comte (1908[1848]) and Herbert Spencer (1865) viewed society as a kind of organism subject to the process of growth. In this view, society moves from simplicity to complexity, from chaos to order, from generalisation to specialisation, and from flexibility to organisation. They further believed that societal growth progresses in identifiable stages and that growth is in fact progress. Each newer, more evolved society is better.

It is against this background that Durkheim's conceptualisation of 'primitive' religion is to be understood. His chosen method in his Elementary forms is to analyse the historical development of religion and to investigate the 
elements that contributed to that development (Durkheim 1995[1912]: 1-4). Like Comte and Spencer, he compares this development with the evolution of biological organisms. In his view, 'primitive' societies correspond to unicellular beings in biology. As discoveries in biology led to the theory of evolution, so the study of primitive society is necessary to understand modern society (Durkheim 1995[1912]: 5-7). From a postcolonial perspective, it remains important to realise that these theories of social evolution developed in the wider context of European imperialism. Although imperial powers settled most differences of opinion with their colonial subjects with force, increased awareness of non-western peoples raised new questions for European scholars about the nature of society and culture. Specifically, the theory of social evolution enabled European scholars to organise knowledge in a way that reflected and justified their increasing political and economic domination of others. The colonised were less evolved and needed the domination of the colonisers to develop.

However, Durkheim's evolutionist ideas also differed from those of his contemporaries in that he focused on elementary structures rather than temporal development. This focus led him to the choice of Australian aboriginal culture in his Elementary forms - widely regarded as his masterpiece, since he believed it to be an eminent example of the most elementary form of religious life rather than the earliest in time. However, this focus on structure, rather than temporal development, may still be problematic. For example, in his work on the division of labour in society, Durkheim suggests that such division positively correlates with the level of a society's advancement. He distinguishes two types of societies, namely mechanical societies and organic societies, more or less corresponding to 'primitive' and 'civilised' cultures (Durkheim 1984[1893]: 31-87). He suggests that the division of labour, as a natural law, fosters social solidarity. In primitive societies, people experience a sense of unity resulting from individuals with similar backgrounds engaging in similar work. This he calls mechanical solidarity. Organic solidarity, which prevails in more advanced societies, results from individuals engaging in different kinds of work that benefit society and other individuals.

Durkheim (1984[1893]: 89) goes on to argue that organic differences between primitive and civilised people also correspond to psychological similarities. He quotes ethnographic work that establishes the absence of strong individuality among "negroid" peoples as they have been observed by slave traders. Physical differences extend to psychological differences associated with labels such as "faithful," "treacherous and perfidious," "good domestic slave but not employable for manual labour," etcetera. He further associates 'primitive' mentality with the acceptance and practice of religion without questioning belief (Durkheim 1984[1893]: 90). In these 'primitive' societies, 
argues Durkheim, religion embraces and extends to everything: "It embraces, although in a very confused state, besides beliefs proper, ethics, law, the principles of political organization, and even science, or at least what passes for it" (Durkheim 1984[1893]: 90). Importantly, the biological and psychological characteristics of 'primitive' peoples predispose them to specific functions and types of labour and make them incapable of change (Durkheim 1984[1893]: 246). As proof for the proposition that members of a "negro" tribe have similar character traits and are therefore suited to specific types of labour, he suggests that African slave dealers only need to enquire about a slave's place of origin, or her tribal identity, in order to deduce whether the slave would be more suitable for domestic work or physical labour (Durkheim 1984[1893]: 89-90). According to Durkheim, it is the task of civilisation to classify 'primitive' peoples according to their abilities and divide labour accordingly. It would seem, therefore, that Durkheim's evolutionist ideas, although much less binary than his contemporaries, still followed in the tradition of Herbert Spencer, who defined it as an inevitable movement towards increasing complexity and order and towards greater diversity (cf. Kuper 1985: 227; Belier 1999: 36).

As demonstrated above, these evolutionist ideas also dominated his later thinking, as expressed in his Elementary forms. In this work, too, Durkheim suggested that the original in time and the simple in structure coincided. Studying the Australian aboriginal people meant going back to the beginnings of history and researching a religion of which the elaborations were not denatured by scientific reflection. It would seem, therefore, that there is more continuity in Durkheim's thought with reference to the concept of unilineal evolution than is sometimes assumed.

However, these evolutionist ideas constitute only one aspect of Durkheim's theory of religion, which still deserves consideration in contemporary thinking about religion. As an alternative to Tylor's animism, Durkheim (1995[1912]) proposed that the earliest form of religion was totemism. It needs to be noted that words such as "totem" and "mana" were taken from so-called 'primitive' societies and used by European scholars to describe similar phenomena in different societies. In totemism, human beings are said to have kinship or a mystical relationship with a spirit being, such as a plant or animal. For Durkheim, however, the totemic principle represented a universal, impersonal, and supernatural power which united society in a moral community. To support this sociological interpretation of the origins of religion, he equated the totemic principle with "mana," which he also defined as a universal and impersonal force as opposed to the animism of Tylor, which focused on individual, personal spirits (Meylan 2017: 43-44).

Many scholars have since criticised the way in which theorists have used terms such as "totem" and "mana" in the nineteenth and early twentieth 
centuries. For example, Lévi-Strauss (1969[1962]: 18) pointed out that the term "totem" comes from a Native American tribe and that the way in which it has been used by Western scholars, such as Durkheim, should not be confused by the belief system associated with the term in the Ojibwa speaking tribe from which it was taken. The term totemism has since fallen out of use. Similarly, Meylan (2017) has criticised the way in which European scholars used the term "mana" in contexts which radically differed from the Melanesian environment in which it originated. Further, Durkheim's theory that totemism, defined as an impersonal force that unites people into a moral community, constituted the most 'primitive' form of religion has since been questioned. Shortly after the publication of his landmark study on the elementary forms of religion, Arnold van Gennep (1873 - 1957), who was an expert on the societies and religions of Australia, questioned the ethnographic data on which Durkheim based his theory. Further, by demonstrating that the Arunta in fact had a complex system of totemic beliefs and practices, he questioned Durkheim's proposition that it constituted the simplest and most 'primitive' form of religion (Van Gennep 2001[1913]; 1906).

However, Durkheim's focus on the social nature and function of religion should be celebrated. His definition of religion as a unified system of belief and practices relative to the sacred, understood as things forbidden or set apart, is still widely used in the sociological study of religion. Further, it seems worthwhile to continue explorations of the close relationship between religion, morality, and society as popularised by Durkheim in his Elementary forms. For example, Rossano (2007) has suggested that religion built on natural moral instincts in humans by including supernatural agents, such as watchful ancestors, spirits, gods, and forces to support cooperation and restrain immorality. In this view, collective religious belief and the social sanction of institutionalised morality clearly had adaptive value and would have enhanced group survival.

\section{Conclusion}

Classical sociology took shape during a time when imperial states, such as the British, French, and German empires claimed political and territorial control over wide stretches of the globe. This paper contributes to the contemporary project of postcolonial analysis by problematising Durkheim's discourse regarding 'primitive' religion. As one of the major European theorists of the late nineteenth and beginning twentieth centuries, Durkheim is often celebrated for his direct criticism of the racist stereotypes of his contemporaries. However, he failed to rid himself of many of the evolutionary assumptions of his time. Although Durkheim tried to break free from evolutionism by focusing on societal structures rather than on temporal development, he still positioned 
'primitive' societies on a lower level of development like many of his contemporaries, who effectively justified the political and economic domination of colonised cultures. Despite his efforts to argue that 'primitive,' or elementary societies were essentially the same as modern Europe, he still regarded them as less developed. Aside from his criticism of racist ideas, therefore, he can still be regarded as unwittingly supporting the imperial and colonial projects of his time. Nevertheless, Durkheim should still be celebrated as a pioneer in the ongoing study of the social nature and function of religion.

Zacharias Kotzé is a research fellow at the University of South Africa. After receiving his DPhil in Ancient Studies from Stellenbosch University in 2004, he has worked at various universities in South Africa where he taught, did research, and developed course material in various subject areas in the human sciences. He has a strong interest in linguistic, sociological, psychological, and anthropological approaches to the study of religion.

\section{REFERENCES}

ASHCROFT, B. - GRIFFITHS, G. - TIFFIN, H., 2013: Key Concepts in Post-Colonial Studies. London: Routledge.

BELIER, W. W., 1999: Durkheim, Mauss, Classical Evolutionism and the Origin of Religion. Method \& Theory in the Study of Religion 11: 24-46. https://doi.org/10.1163/157006899X00375

CALLAWAY, H., 1868 - 1870: The Religious System of the Amazulu. Springvale: Springvale Mission Press.

CHIDESTER, D., 2014: Empire of Religion: Imperialism and Comparative Religion. Chicago: University of Chicago Press. https://doi.org/10.7208/chicago/9780226117577.001.0001

COMTE, A., 1908 [1848]: A General View of Positivism. or, Summary Exposition of the System of thought and Life. Translated by John H. Bridges. London: George Routledge and Sons.

DURKHEIM, É., 1984[1893]: The Division of Labour in Society. Translated by W. D. Halls. London: Macmillan. https://doi.org/10.1007/978-1-349-17729-5

DURKHEIM, É., 1951[1897]: Suicide. A Study in Sociology. Translated by J. A. Spaulding and G. Simpson. London: Routledge.

DURKHEIM, É., 1995[1912]: The Elementary Forms of Religious Life. Translated by Karen E. Fields. New York: Free Press.

DURKHEIM, É., 2012[1912]: The Elementary Forms of Religious Life. Translated by Joseph W. Swain. London: George Allen \& Unwin.

FANON, F., 1968[1952]: Black Skin, White Masks. Translated by C. L. Markmann. London: Paladin.

FANON, F., 1967[1961]: The Wretched of the Earth. Translated by C. Farrington. Harmondsworth: Penguin.

GANDHI, L., 1998: Postcolonial Thinking: A Critical Introduction. Crows Nest: Allen \& Unwin.

GOULET, N., 2011: Postcolonialism and the Study of Religion: Dissecting Orientalism, Nationalism, and Gender Using Postcolonial Theory. Religion \& Compass 5(10): 631-637. https://doi.org/10.1111/j.1749-8171.2011.00306.x 
KUPER, A., 1985: Durkheim's Theory of Primitive Kinship. The British Journal of Sociology 36(2): 224-237. https://doi.org/10.2307/590802

KUPER, A., 2005: The Reinvention of Primitive Society: Transformations of a Myth. London: Routledge. https://doi.org/10.4324/9780203003527

LÉVI-STRAUSS, C., 1969[1962]: Totemism. Translated by R. Needham. London: Merlin.

MERLLIÉ, D., 2012: Durkheim, Lévy-Bruhl et la 'pensée primitive': Quel differend?" L'Année sociologique 62: 429-446. https://doi.org/10.3917/anso.122.0429

MEYLAN, N., 2017: Mana: The History of a Western Category. Leiden: Brill. https://doi.org/10.1163/9789004349247

ROSSANO, M., 2007: Supernaturalising Social Life: Religion and the Evolution of Human Cooperation. Human Nature 18(3): 272-294. https://doi.org/10.1007/s12110-007-9002-4

SAID, E., 1979: Orientalism. New York: Vintage Books.

SPENCER, H., 1865: First Principles of a New System of Philosophy. New York: D. Appleton and Company.

THOMASSEN, B., 2016: The Hidden Battle that Shaped the History of Sociology: Arnold van Gennep Contra Émile Durkheim. Journal of Classical Sociology 16(2) 173-195. https://doi.org/10.1177/1468795X15624191

TYLOR, E. B., 1871: Primitive Culture: Researches into the Development of Mythology, Philosophy, Religion, Language, Art and Custom. London: John Murray.

VAN GENNEP, A., 1906: Mythes et légendes d'Australie: Études d'ethnographie et de sociologie. Paris: E. Guilmoto.

VAN GENNEP, A., 2001[1913]: Durkheim, Les formes élémentaires de la vie religieuse. In: Privat, Jean-Marie (ed.): Chroniques de folklore d'Arnold Van Gennep: recueil de textes parus dans le "Mercure de France", 1905-1949, 92-95. Paris: Comité des travaux historiques et scientifiques.

VOGT, W. P., 1976: The Uses of Studying Primitives: A Note on the Durkheimians, $1890-$ 1940. History and Theory 15(1): 33-44. https://doi.org/10.2307/2504875

WITYAK, N. L. - WALLACE, R. A., 1981: Durkheim's Non-Social Facts about Primitives and Women. Sociological Inquiry 51(1): 61-67.

https://doi.org/10.1111/j.1475-682X.1981.tb01027.x

Sociológia 53, 2021, No. 3 